\title{
REVIEW
}

\section{THE DEVELOPMENT OF DIGITAL ECONOMY IN INDONESIA}

Ahmad Zafrullah Tayibnapis, Lucia Endang Wahyuningsih, dan Radita Gora

\begin{tabular}{|l|l|}
\hline Jurnal & International Journal of Management and Business studies \\
\hline Vol. \& Hal. & Volume 8, 18 halaman \\
\hline Tahun & 2018 \\
\hline Penulis & Ahmad Zafrullah Tayibnapis \\
\hline
\end{tabular}

\begin{tabular}{|c|c|}
\hline Abstrak & $\begin{array}{l}\text { Di Indonesia, pengguna internet serta pengeluaran masyarakat untuk } \\
\text { belanja online tergolong tinggi. Di Asia Tenggara, e-commerce juga } \\
\text { berkembang pesat, layaknya perkembangan digital (gaya hidup maupun } \\
\text { teknologi) yang dapat menjadi ancaman bagi bisnis tradisional dan } \\
\text { konvensional. Generasi milenial menjadi target utama dalam peningkatan } \\
\text { pangsa pasar, oleh sebab itu, dilakukanlah penelitian terhadap UMKM dan } \\
\text { perilaku konsumen. Hasilnya terlihat bahwa terdapat berbagai masalah } \\
\text { yang harus segera diatasi : regulasi, kolaborasi, infrastruktur. }\end{array}$ \\
\hline Pendahuluan & $\begin{array}{l}\text { Berdasarkan penelitian dari Tayibnapis, A.Z (2012), dapat dilihat bahwa } \\
\text { pertama, saat ini, di era Industri 4.0, semua menjadi berbasis teknologi, } \\
\text { tidak terkecuali layanan keuangan (seperti asuransi, transfer, simpanan dan } \\
\text { pinjaman, dan lainnya), menjadi berkembang pesat di Indonesia. Perubahan } \\
\text { ini berarti teknologi memiliki peranan penting untuk akses layanan } \\
\text { keuangan, manfaat ini dapat dirasakan oleh UMKM dan konsumen. Kedua, } \\
\text { layanan keuangan yang semakin berkembang, muncul internet banking, } \\
\text { mobile banking, e-money, dan lain hal yang bisa diakses melalui } \\
\text { smartphone. Ketiga, teknologi keuangan dapat membantu pembangunan } \\
\text { infrasturuktur perbankan yang dapat meningkatkan daya beli konsumen. } \\
\text { Singapura, Jepang, dan Amerika menunjukkan dampak dari perubahaan ini } \\
\text { pada pertumbuhan ekonomi dan kestabilan sistem keuangan. Keempat, } \\
\text { ekonomi digital dapat menjadi ancaman bagi industry perbankan : cyber } \\
\text { crime. }\end{array}$ \\
\hline $\begin{array}{l}\text { Kajian } \\
\text { Pustaka }\end{array}$ & $\begin{array}{l}\text { Tayibnapis, A.Z (2012) dalam penelitiannya menjelaskan beberapa teori } \\
\text { dan konsep dasar seperti : } \\
\text { 1. Sistem Keuangan di Indonesia dibagi menjadi dua yaitu lembaga } \\
\text { penyimpanan keuangan dan lembaga non-penyimpanan keuangan. } \\
\text { 2. Sistem keuangan yang stabil dapat mempengaruhi sirkulasi jumlah } \\
\text { uang beredar di indonesia, membuat inflasi dapat dikendalikan dan } \\
\text { meningkatkan kebutuhan sektor utama, sekunder dan tersier. } \\
\text { 3. Terdapat } 3 \text { motif permintaan uang yaitu motif transaksi, motif } \\
\text { kehati-hatian dan motif spekulatif } \\
\text { 4. Permintaan uang tidak hanya dipengaruhi oleh pendapatan dan } \\
\text { suku bunga, tetapi faktor lain seperti sistem pembayaran, fasilitas } \\
\text { kredit dengan bunga lunak, dan lain-lain. }\end{array}$ \\
\hline
\end{tabular}




\begin{tabular}{|c|c|}
\hline & $\begin{array}{l}\text { 5. E-Bisnis sekarang sangat berkembang pesat di Indonesia, dimana } \\
\text { tidak hanya berfokus pada aktivitas jual beli saja, tetapi juga } \\
\text { melayani dan kolaborasi dengan mitra bisnis lainnya. }\end{array}$ \\
\hline $\begin{array}{l}\text { Metode } \\
\text { penelitian }\end{array}$ & $\begin{array}{l}\text { Penelitian yang dilaksanakan oleh Tayibnapis, A.Z (2012) termasuk } \\
\text { penelitian kualitatif karena penelitian ini berusaha memahami fenomena } \\
\text { ekonomi digital dari pengguna internet dan perkembangan pesat dari } \\
\text { financial technology, serta permintaan konsumen untuk instrumen } \\
\text { pembayaran dengan menggunakan kartu. Data yang digunakan adalah data } \\
\text { primer dari } 100 \text { responden dan data sekunder dari berbagai sumber yang } \\
\text { valid. }\end{array}$ \\
\hline $\begin{array}{l}\text { Hasil } \\
\text { penelitian }\end{array}$ & $\begin{array}{l}\text { Dalam penelitian yang dilakukan oleh Tayibnapis, A.Z (2012) dapat } \\
\text { ditemukan hambatan dalam ekonomi digital ini yaitu, bisnis online dan } \\
\text { bisnis pinjaman peer-to-peer tanpa jaminan dapat menyebabkan rasa tidak } \\
\text { aman saat tidak dilakukan hati-hati dan kurangnya regulasi dan } \\
\text { infrastruktur dari pemerintah. } \\
\text { Oleh karena itu berdasarkan penelitian ini, Tayibnapis, A.Z (2012) } \\
\text { menemukan beberapa gagasan untuk mengembangkan ekonomi digital di } \\
\text { Indonesia seperti : } \\
\text { 1. Pemanfaatan teknologi dapat membantu manusia dalam perkembangan } \\
\text { perekonomian. } \\
\text { 2. Teknologi digital merupakan suatu terobosan untuk memudahkan suatu } \\
\text { transaksi yaitu lebih murah, lebih praktis, lebih cepat, dan lebih efisien. } \\
\text { 3. Bisnis mulai beralih dari konvensional menjadi berbasis teknologi } \\
\text { dengan online, sehingga belanja lebih mudah dan pergerakan } \\
\text { perekonomian lebih cepat. } \\
\text { 4. UMKM harus berani melakukan langkah-langkah yang main stream } \\
\text { supaya bisa bertahan dengan melakukan bisnis secara digital dan } \\
\text { inovatif. }\end{array}$ \\
\hline Kesimpulan & $\begin{array}{l}\text { Dari penelitian yang dilaksanakan oleh Tayibnapis, A.Z (2012) didapatkan } \\
\text { beberapa kesimpulan seperti : } \\
\text { 1. 1. Dalam teknologi dgital harus ada jaminan server tidak down. } \\
\text { 2. 2. Bisnis dengan teknologi online masih perlukan rasa saling percaya } \\
\text { karena } \\
\text { 3. 3. antara konsumen dan supply tidak saling mengenal. } \\
\text { 4. 4. Teknologi digital merupakan suatu terobosan untuk memudahkan suatu } \\
\text { transaksi yaitu lebih murah, lebih praktis, lebih cepat, dan lebih efisien. }\end{array}$ \\
\hline Kelebihan & $\begin{array}{l}\text { 1. Penulis memiliki keberanian mengutarakan pendapat walaupun dalam } \\
\text { pembahasan ada pertentangan. } \\
\text { 2. Penulis memberikan solusi dengan mengeluarkan angka secara } \\
\text { numerik dengan adanya analisa pembuktian. } \\
\text { 3. Penulisan dilakukan dengan sistematis dan teratur sehingga dapat } \\
\text { dibaca dengan mudah oleh orang yang awam. }\end{array}$ \\
\hline
\end{tabular}




\begin{tabular}{|l|l|}
\hline Kekurangan & $\begin{array}{l}\text { Penulis belum terlalu membahas dampak-dampak yang dapat terjadi dari } \\
\text { ekonomi digital ini seperti : }\end{array}$ \\
$\begin{array}{l}\text { 1. } \\
\text { Dari segi penggunaan ekonomi digital ini akan menyusahkan bagi para } \\
\text { konsumen yang berada di daerah pedalaman karena kurangnya } \\
\text { jaringan internet/listrik. }\end{array}$ \\
\begin{tabular}{l} 
2. $\begin{array}{l}\text { Dengan adanya teknologi digital ini akan memberikan dampak buruk } \\
\text { bagi bisnis-bisnis tradisional. }\end{array}$ \\
\hline
\end{tabular}
\end{tabular}

\begin{tabular}{|l|lr|l|}
\hline Reviewer & Sheiren & 130218085 & KP G \\
& Merelyn & 130318005 & \\
& Stephania Eryn & 130318013 & \\
& Shania G & 130318018 & \\
& Matthew J & 130318034 & \\
\hline
\end{tabular}


